\title{
Immunotherapy for Alzheimer's disease
}

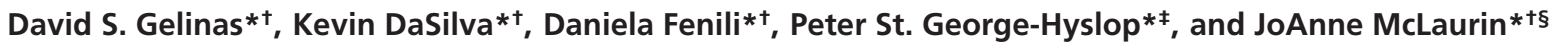 \\ *Centre for Research in Neurodegenerative Diseases, University of Toronto, 6 Queen's Park Crescent West, Toronto, ON, Canada M5S 3H2; ${ }^{\dagger}$ Departments of \\ Laboratory Medicine and Pathobiology, University of Toronto, Toronto, ON, Canada M5S 3H2; and ₹Department of Medicine, University of Toronto, \\ Toronto, ON, Canada M5S $3 \mathrm{H} 2$
}

The utility of vaccine strategies to treat neurodegenerative diseases such as Alzheimer's disease (AD) may still hold promise. Both active and passive immunization strategies reduced AD-like pathology and restored cognitive deficits in transgenic mice. These results were initially met with considerable optimism; however, phase lla clinical trials were halted because of a small but significant occurrence of meningoencephalitis. Knowledge gained from studies on amyloid- $\beta$ peptide $(A \beta)$ immunotherapy will allow optimization of new-generation vaccines, targeting highly specific epitopes while reducing undesired side effects. In harnessing and steering the immune system, an effective response can be generated against $A \boldsymbol{\beta}$. If this proves successful, $A \boldsymbol{\beta}$ vaccination could provide the first definitive treatment for $A D$.

A lzheimer's disease (AD) is the most common cause of age-related cognitive decline, affecting $>12$ million people worldwide (1). The disease is characterized in its earlier stages by progressive memory impairment and cognitive decline, altered behavior, and language deficits. Later, patients present with global amnesia and slowing of motor functions, with death typically occurring within 9 years after diagnosis (2). Current drug therapy aims at slowing cognitive decline and ameliorating the affective and behavioral symptoms associated with disease progression. However, these drugs provide limited symptomatic treatment, without targeting the underlying cause of AD. Immunization of AD patients provides a novel means of specifically targeting the neurotoxic effects of amyloid- $\beta$ peptide $(\mathrm{A} \beta)$ and thereby targeting disease progression.

\section{The Amyloid Cascade Hypothesis}

The main constituent of amyloid consists of a 40- to 43-aa peptide, $\mathrm{A} \beta$, and is derived from the proteolytic cleavage of a family of ubiquitously expressed membrane-spanning proteins, termed the amyloid precursor proteins (APP) (3). Under normal conditions, the most abundant species in the brain is the $\mathrm{A} \beta$ (1-40) peptide $\left(\mathrm{A} \beta_{40}\right)$; however, much of the fibrillar $\mathrm{A} \beta$ is composed of the longer, more fibrillogenic $\mathrm{A} \beta$ (1-42) peptide $\left(\mathrm{A} \beta_{42}\right)(3)$. These normally soluble peptides undergo conformational change and polymerize into an aggregated and toxic form, rich in $\beta$-structure (4). Initially, $\mathrm{A} \beta_{42}$ is deposited in an immature, diffuse (nonfibrillar) plaque, with little or no detectable neuritic dystrophy.

Early studies have shown that synthetic fibrillar forms of $\mathrm{A} \beta$ are toxic to cultured neurons (5-7). Several mechanisms of $\mathrm{A} \beta$-induced neurotoxicity have been proposed, including oxidative stress, free-radical formation, disrupted calcium homeostasis, induction of apoptosis, chronic inflammation, and activation of complement (8). Although it has been shown that increased levels of $\mathrm{A} \beta$ in the brain correlate with cognitive decline (9), relatively weak correlations exist between fibrillar amyloid plaque density and severity of dementia (10-12). Recent studies point to other forms of $\mathrm{A} \beta$, namely, small oligomers as the neurotoxic species $(13,14)$.

Recent reports using antibodies raised against synthetic $\mathrm{A} \beta$ oligomers detected a 70-fold increase in oligomeric species in
AD patients over control brains (15). Moreover, Kayed et al. (16) found that soluble oligomers display a common conformationdependent structure common to all oligomers independent of their sequence, which suggests a shared mechanism of toxicity. Functionally, it has been found that naturally secreted oligomers inhibit hippocampal long-term potentiation in vivo (17). Taken together, these results suggest that strategies aimed at treating amyloid disorders should target oligomers of $A \beta$. In doing so, the equilibrium between monomers and higher-order aggregates can be disrupted, resulting in neutralization of soluble, toxic species.

\section{Immunization Against $\mathbf{A} \boldsymbol{\beta}$ in Transgenic Mouse Models of AD}

Since Schenk et al. (18) first reported that immunization of PDAPP mice with synthetic, preaggregated $A \beta_{42}$ reduced the extent and progression of AD pathology (Fig. 1), much progress has been made in designing a vaccine appropriate for human use. Several strategies, including active and passive immunization, have been explored (Table 1), which not only hold promise as potential therapeutics but also address both the cognitive dysfunction and $\mathrm{A} \beta$ accumulation.

\section{Mechanisms of Action}

Although active and passive immunization strategies have proven efficacious in mouse models of $\mathrm{AD}$, it remains unclear how antibodies elicit this effect. Several hypotheses have been put forth to explain results observed in vivo and in vitro, but it is important to note that these are not mutually exclusive. Any number of these mechanisms may act under a given set of circumstances, with factors including the epitope, isotype, and amyloid burden likely to influence the primary means of clearance or sequestration.

Microglial Mediated Phagocytosis. Bard et al. (23) presented a model whereby peripherally administered antibodies enter the $\mathrm{CNS}$ and bind $\mathrm{A} \beta$ fibrils, with subsequent recruitment of microglia to phagocytose the complex by means of $\mathrm{Fc}$ receptor ligation. Ex vivo assays confirm the presence of internalized $\mathrm{A} \beta$ within microglia upon incubation with anti-A $\beta$ antibodies and tissue sections. Follow-up studies were consistent with these observations, because the most effective antibodies (examined in vivo and ex vivo) were of the $\mathrm{IgG} 2 \mathrm{a}$ isotype, which exhibits high affinity for $\mathrm{Fc}$ receptors on microglia (25). Microglial activation was also found to accompany plaque clearance in vivo by both active and passive immunization strategies $(24,26)$ or in contrast to decrease activation in active immunization in the TgCRND8

This paper results from the Arthur M. Sackler Colloquium of the National Academy of Sciences, "Therapeutic Vaccines: Realities of Today and Hopes for Tomorrow," held April $1-3,2004$, at the National Academy of Sciences in Washington, DC.

Abbreviations: $A D$, Alzheimer's disease; $A \beta$, amyloid- $\beta$ peptide; APP, amyloid precursor proteins; Th, T helper.

§To whom correspondence should be addressed at: Centre for Research in Neurodegenerative Diseases, Tanz Neuroscience Building, 6 Queen's Park Crescent West, Toronto, ON Canada M5S 3H2. E-mail: j.mclaurin@utoronto.ca.

C 2004 by The National Academy of Sciences of the USA 


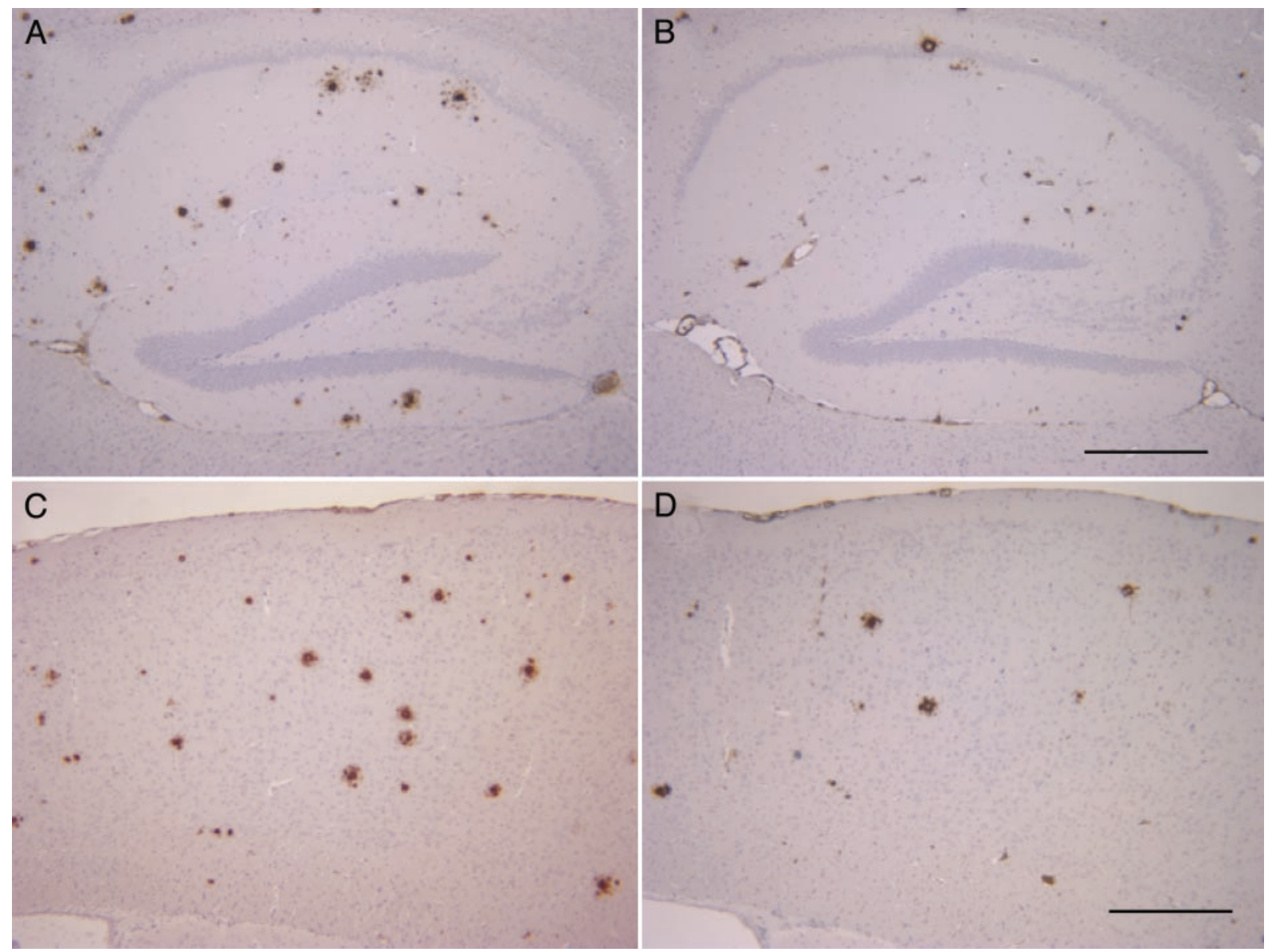

Fig. 1. A $\beta 42$-immunized TgCRND8 mice have a $50 \%$ reduction in plaque burden than untreated TgCRND8 mice. Representative pictures of the distribution of $A \beta$ plaques labeled by Dako $6 \mathrm{~F} / 3 \mathrm{D}$ anti-A $\beta$ antibody in the hippocampus $(A$ and $B)$ and cortex $(C$ and $D)$ of control peptide-immunized $(A$ and $C)$ and A $\beta 42$-immunized TgCRND8 mice $(B$ and $D)$. (Scale bars $=100 \mu \mathrm{m}$.)

mouse model (Fig. 2) (20). However, recent reports suggest that multiple clearance mechanisms may act in concert to clear amyloid plaques $(28,32)$. Immunization of $\mathrm{Tg} 2576$ mice crossed with $\mathrm{Fc}$ receptor gamma knockout mice were as efficient at clearing plaques as Tg2576 mice alone, further supporting the idea of multiple clearance pathways (32). Another possibility involves internalization of $\mathrm{A} \beta$ /antibody microaggregates by microglia through the type A scavenger receptor (37). Indeed, a recent report from Wilcock et al. (33) suggests a two-phase mechanism of anti-A $\beta$ antibody action, both independent and associated with microglial activation. This report suggests that down-regulation of microglial activation either through the use of $F(a b)$ fragments or antiinflammatory drugs severely reduces the clearance of compact fibrillar but not diffuse plaques (38). Therefore, microglial activation may be necessary for efficient clearance of senile plaques from the CNS. If this is indeed the case, then a fine balance must be struck to clear plaques without eliciting further damage to the surrounding CNS milieu.

Peripheral Sink Hypothesis. An alternate mechanism comes from the observation that long-term peripheral administration of a monoclonal antibody $(\mathrm{m} 266)$ results in a rapid increase in plasma $\mathrm{A} \beta$ with subsequent reduction in amyloid burden, without binding of $\mathrm{m} 266$ to $\mathrm{A} \beta$ deposits in the brain (24). These results suggested that sequestration of plasma $\mathrm{A} \beta$ disrupts the $\mathrm{A} \beta$ equilibrium between the CNS and plasma, resulting in increased efflux of $\mathrm{A} \beta$ out of the brain, into the periphery where it is degraded. This hypothesis is supported by a number of obser- vations. $\mathrm{A} \beta$-peptides have been shown to be transported readily between the CNS and plasma (39-41). Moreover, in nondemented patients, i.v. infusion of anti-A $\beta$ antibodies led to increased $\mathrm{A} \beta$ levels in the plasma, with concomitant decreases in $\mathrm{A} \beta$ within the cerebrospinal fluid (42). These findings are further supported by Lemere et al. (34), who observed a 28 -fold increase in serum $\mathrm{A} \beta$ after chronic, active immunization of PSAPP mice.

Inhibition of Fibrillogenesis and Cytotoxic $\mathbf{A} \boldsymbol{\beta}$ Species. Previous work by Solomon and colleagues (43-45) predicted that antibodies raised against the $\mathrm{N}$ terminus of $\mathrm{A} \beta$ could inhibit in vitro aggregation and could bind to preexisting $A \beta$ fibrils, resulting in disaggregation and protection from their neurotoxic effects. We extended this line of evidence by demonstrating that antibodies directed against residues 4-10 of A $\beta 1-42$ inhibit both fibrillogenesis and cytotoxicity, without eliciting a harmful cytotoxic $\mathrm{T}$ cell response in TgCRND8 mice (20). Consistent with these results are studies by Bard et al. (25) demonstrating that plaque clearance is only seen with antibodies directed against the $\mathrm{N}$-terminal region of $\mathrm{A} \beta$. Furthermore, a single administration of anti-A $\beta 3-6$ IgG1 was effective at plaque clearance and resolution of neuritic lesions within 4 days and lasted up to 32 days in the PDAPP mouse (46). These results support the use of passive immunization strategies because, once plaques are cleared, neuronal morphology is restored and therefore may have a direct impact on cognitive function.

We also suggested that antibodies induced by immunization of 
Table 1. Summary of vaccine studies in transgenic mouse models of AD

\begin{tabular}{|c|c|c|c|c|c|}
\hline Model & Treatment (age) & Active/passive (route) & Treatment schedule & Effect & $\operatorname{Ref}(s)$. \\
\hline TgCRND8 & Prophylactic (6 wk) & Active & Chronic (19 wk) & $\begin{array}{l}\downarrow \text { A } \beta \text { levels } \\
\downarrow \text { Pathology } \\
+ \text { Behavior }\end{array}$ & 19,20 \\
\hline \multirow[t]{6}{*}{ PDAPP } & Prophylactic (6 wk) & Active & Chronic (11 mo) & $\begin{array}{l}\downarrow \text { A } \beta \text { levels } \\
\downarrow \text { Pathology }\end{array}$ & 18 \\
\hline & Treatment (11 mo) & Active & Chronic (8 mo) & $\begin{array}{l}\downarrow \mathrm{A} \beta \text { levels } \\
\downarrow \text { Pathology }\end{array}$ & 18 \\
\hline & Prophylactic (5 mo) & Active (nasal) & Chronic (7 mo) & $\begin{array}{l}\downarrow \text { A } \beta \text { levels } \\
\downarrow \text { Pathology }\end{array}$ & 21,22 \\
\hline & Prophylactic (8-20 mo) & Passive & Chronic (6 mo) & $\begin{array}{l}\downarrow \text { A } \beta \text { levels } \\
\downarrow \text { Pathology }\end{array}$ & $23-25$ \\
\hline & Treatment (11-24 mo) & Passive & Acute & $\begin{array}{l}\downarrow \text { A } \beta \text { levels } \\
+ \text { Behavior }\end{array}$ & $26-28$ \\
\hline & Prophylactic (1 and $12 \mathrm{mo}$ ) & Active (viral) & Chronic & $\begin{array}{l}\downarrow \mathrm{A} \beta \text { levels } \\
\downarrow \text { Pathology } \\
+ \text { Behavior }\end{array}$ & 29 \\
\hline \multirow[t]{4}{*}{$\operatorname{Tg} 2576$} & Prophylactic (7-8 mo) & Active & Chronic & $\begin{array}{l}\downarrow \text { A } \beta \text { levels } \\
\downarrow \text { Pathology } \\
+ \text { Behavior }\end{array}$ & 30,31 \\
\hline & Prophylactic (10-11 mo) & Active & Chronic (4 mo) & $\begin{array}{l}\downarrow \text { A } \beta \text { levels } \\
\downarrow \text { Pathology }\end{array}$ & 31 \\
\hline & Treatment (18 mo) & Active & Chronic (4 mo) & $\begin{array}{l}\downarrow A \beta \text { levels } \\
N C \text { pathology }\end{array}$ & 31 \\
\hline & Treatment (10-18 mo) & Passive (intracranial) & Acute & $\begin{array}{l}\downarrow A \beta \text { levels } \\
\downarrow \text { Pathology }\end{array}$ & 24,26 \\
\hline $\operatorname{Tg} 2576\left(\mathrm{FcR} \gamma^{-/-}\right)$ & Treatment (11-15 mo) & Active (i.p.) & Chronic (3 mo) & $\downarrow \mathrm{A} \beta$ levels & 32 \\
\hline $\mathrm{APP}+\mathrm{PS} 1$ & Treatment (7.5-14.5 mo) & Active & Chronic (5 injections) & $\begin{array}{l}\downarrow \mathrm{A} \beta \text { levels } \\
\downarrow \text { Pathology } \\
\text { NC behavior }\end{array}$ & 33 \\
\hline PSAPP & Prophylactic (5 wk) & Active (i.p./nasal) & Chronic (8 wk) & $\begin{array}{l}\downarrow \mathrm{A} \beta \text { levels } \\
\downarrow \text { Pathology }\end{array}$ & 34 \\
\hline APP23 & Prophylactic (21 mo) & Passive (i.p.) & Chronic (5 mo) & $\begin{array}{l}\downarrow \mathrm{A} \beta \text { levels } \\
\uparrow \text { Cerebral } \\
\text { hemorrhages }\end{array}$ & 35 \\
\hline $\mathrm{C} 57 \mathrm{BL} / 6$ & $6-8 w k$ & Active & Acute & $\begin{array}{l}\text { Autoimmune } \\
\text { encephalomyelitis }\end{array}$ & 36 \\
\hline
\end{tabular}

Pathology is defined as amyloid plaque load. NC, no change.

TgCRND8 mice likely target only a subset of $\mathrm{A} \beta$, namely soluble species such as protofibrils or oligomers (20). This suggestion seems likely because total $\mathrm{A} \beta$ brain levels do not decrease after immunization of TgCRND8 mice (19), and several independent studies have presented similar findings $(27,47,48)$.

\section{$\mathbf{A} \boldsymbol{\beta}$ Vaccination in Humans}

After promising preclinical results in several species (mice, rabbits, guinea pigs, and monkeys), clinical trials using $\mathrm{A} \beta_{42}$ (AN-1792) in conjunction with the $\mathrm{T}$ helper (Th) 1 adjuvant QS-21 were initiated $(42,49)$. Although results of phase I trials showed good tolerability, phase IIa trials were halted when 18 of 298 patients immunized with AN-1792 presented with symptoms consistent with meningoencephalitis $(50,51)$. Several reports have since been published regarding the neuropathology and clinical outcome of acute immunization, which should prove useful in designing new generation vaccines (51-55).
Several findings provide hope for AD patients despite the termination of clinical trials. Postmortem examination of two $\mathrm{AD}$ patients who received injections of $\mathrm{AN}-1792$ revealed absent or sparse plaques in the neocortex, lacking dystrophic neurites or reactive astrocytes (as compared with unimmunized controls); reactive microglia in association with areas devoid of plaques; and decoration of plaques by $\mathrm{IgG}$ and $\mathrm{C} 3$ complement. Taken together, these results suggest that an effective immune response was generated that resulted in clearance of $\mathrm{A} \beta$ from the patient (53). Moreover, Hock et al. (54) showed that patients who generate antibodies exhibit slower rates of cognitive decline; this effect was even observed in patients who experienced transient episodes of meningoencephalitis. Neither case altered cerebrovascular amyloid; in the latter case, multiple small hemorrhages, including acute lesions and lesions with macrophages filled with hemosyderin, were detected in the cerebral cortex. It is unclear whether these lesions have a direct link to immunization; however, a report of increased incidence of microhemorrhages in 

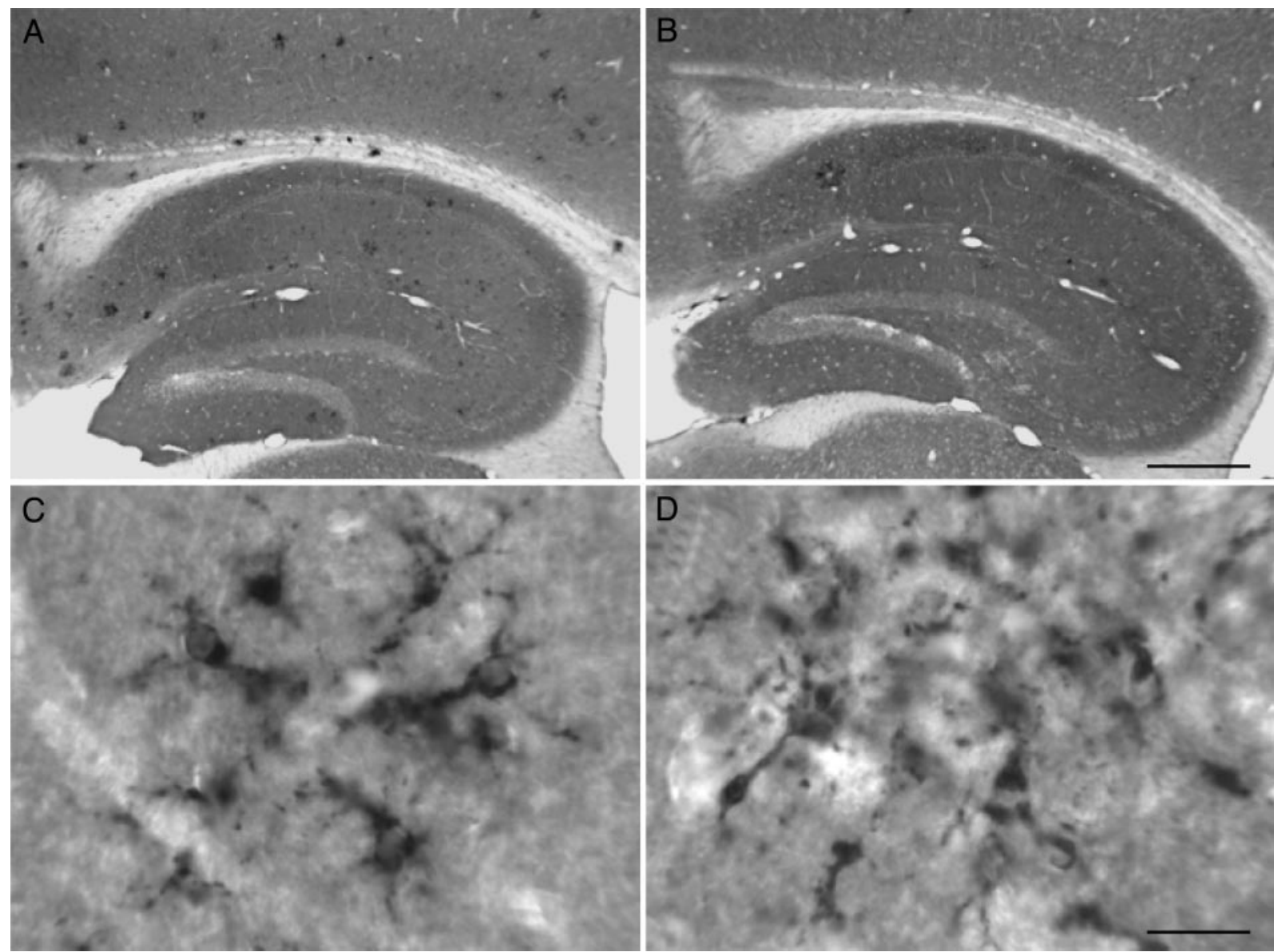

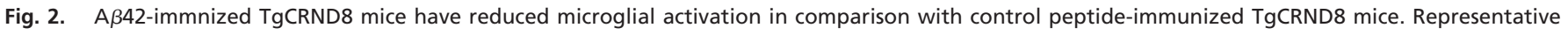

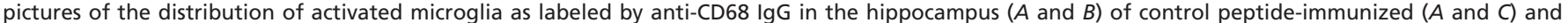

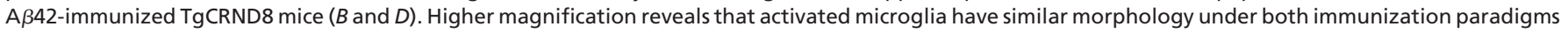
$(C$ and $D)$. [Scale bars $=75 \mu \mathrm{m}(A$ and $B)$ and $5 \mu \mathrm{m}(C$ and $D)$.]

APP23 mice after passive A $\beta$ immunotherapy was reported (35). These studies suggested that $\mathrm{AD}$ patients may need to be screened for the presence and severity of cerebral amyloid angiopathy before initiating $\mathrm{A} \beta$ immunotherapy.

Neuropathological analysis also revealed infiltration of $\mathrm{T}$ lymphocytes, predominantly of the $\mathrm{CD} 4^{+}$type in one patient and the $\mathrm{CD}^{+}$type in the other, and abnormalities of cerebral white matter, including extensive macrophage infiltration and a reduction in the density of myelinated fibers (53). Although no inflammatory reaction was observed in preclinical trials, a recently published report demonstrates that vaccination of $\mathrm{C} 57 \mathrm{BL} / 6$ mice with $\mathrm{A} \beta$ and pertussis toxin induces autoimmune encephalomyelitis, with characteristics (inflammatory foci in the CNS containing macrophages, $\mathrm{B}$ and T cells, circulating anti-A $\beta$ antibodies, and a predominantly $\mathrm{CD} 4^{+}$-mediated $\mathrm{Th} 1$ response) similar to those observed in humans (36).

The inflammatory response observed in human subjects is probably attributable to a $\mathrm{T}$ cell-mediated event $(9,56)$. Infiltration of activated $\mathrm{T}$ cells had been predicted well before commencement of clinical trials (57). T cell epitopes have been mapped to the mid- to carboxy-terminal region (residues 15-42) of $\mathrm{A} \beta$ (Fig. 3) (58). We subsequently showed that antibodies directed toward the $\mathrm{N}$ terminus (residues 4-10) were sufficient to inhibit cytotoxicity and fibrillogenesis without eliciting an inflammatory response (20). Thus, immunization with the fulllength $\mathrm{A} \beta 1-42$ peptide, containing both $\mathrm{B}$ and $\mathrm{T}$ cell epitopes, would be expected to result in extensive $\mathrm{T}$ cell activation. Recent reports of increased $\mathrm{T}$ cell reactivity in $\mathrm{AD}$ patients and older humans, predominantly against amino acids $16-33$ of $\mathrm{A} \beta$, seem in line with these predictions. These results become difficult to interpret, however, in light of contradictory reports indicating that lymphocytes from AD patients exhibit weak proliferative responses to $\mathrm{A} \beta$ and other synthetic peptides corresponding to parts of the APP sequence, as compared with young and aged healthy individuals (59). Moreover, APP transgenic mice were found to be hyporesponsive to human $\mathrm{A} \beta$, in terms of humoral and cellular immune responses (60), suggesting that increased production of $\mathrm{A} \beta$ from such a young age may induce a form of central and peripheral $\mathrm{T}$ cell tolerance.

\section{Future Perspectives}

The AN-1792 trials highlighted the importance of a directed immune response. Many factors, such as antigen, adjuvant, and delivery systems, can be modified to elicit specific cellular and humoral responses. Given the distinct location of B and T cell epitopes within $\mathrm{A} \beta$, new immunogens can be designed which lack the irrelevant $C$ terminus but retain those residues (4-10) required for binding to $\mathrm{A} \beta$ (Fig. 3) (20). Sigurdsson et al. (61)

\section{DAEFRHDSGY ${ }_{10}$ EVHHQKLVFF $_{20}$ AEDVGSNKGA $_{30} I_{\text {IGLMVGGVV }} \mathrm{IA}$

$$
\overrightarrow{B \text {-Cell Epitope }} \quad \text { T-Cell Activation Sites }
$$

Fig. 3. The sequence of $B$ and $T$ cell epitopes within the $A \beta 1-42$ amino acid sequence as determined by mathematical algorithms. 
have demonstrated that immunization with a synthetic nontoxic/ nonfibrillar $\mathrm{A} \beta$ homologous peptide could reduce AD pathology and potentially offer a safer alternative than immunization with A $\beta 1-42$. Lemere and colleagues (62) have shown that when administered nasally $\mathrm{A} \beta 1-15$ was not as efficient as $\mathrm{A} \beta 1-42$ at priming an immune response but was equally efficient at boosting titers. Elan's experimental vaccine has been further examined, and it has been found that patients who developed the inflammatory response recognized the tail end of $\mathrm{A} \beta$, exactly the same as patients who do not (63). These results suggest that modifying the antigen alone may not be sufficient to avoid encephalitogenic responses in all patients.

Immune responses will also need to be directed toward a Th2 response, which promotes antibody production, down-regulates proinflammatory Th1 responses, and results in the release of antiinflammatory cytokines that have the potential to mitigate chronic inflammatory conditions already present in AD patients (64). This is particularly important given recent findings that microglia-mediated release of nitric oxide by $\mathrm{A} \beta$-reactive Th1 cells can contribute to AD neurotoxicity; Th2 cells, however, were found to counterbalance the toxic effects of NO (65). Nasal immunization paradigms have illustrated the potential to decrease AD pathology while inducing the expression of the antiinflammatory cytokines IL-4, IL-10, and transforming growth factor beta $\beta$ (TGF- $\beta)(21,22)$. Wyss-Coray et al. (66) have demonstrated that modest increases in astroglial production of TGF- $\beta 1$ results in a marked reduction in plaque burden and overall $A \beta$ load, presumably through promotion of microglia. The choice of adjuvant used in a vaccine protocol will also have modulatory effects on the Th1 versus Th2 responses. Nontransgenic mice immunized with A $\beta 1-42$ mixed with Alum induce primarily a Th2 response, whereas TitreMax Gold, complete Freund's adjuvant, and QS21 induce predominantly a Th1 response (67). Furthermore the use of costimulatory molecules or chemokines to target effective antigen presentation by dendritic cells in the lymph nodes have been successful in in vivo models of AIDS and cancer $(68,69)$.

Rangan et al. (70) have identified recombinant antibody light-chain fragments with proteolytic activity, capable of hydrolyzing $\mathrm{A} \beta$ in vitro. Although these fragments currently demonstrate broad substrate specificity, they may prove therapeutically useful if the antibody could be engineered to specifically target pathogenic forms of $\mathrm{A} \beta$, such as oligomers or protofibrils. Also, Frenkel et al. (71) suggested a novel approach, where intracellular expression of a site-directed single-chain antibody, which has been shown to inhibit fibrillogenesis and cytotoxicity in vitro, could target $\mathrm{A} \beta$ before it is released from the cell.

DNA vaccines or viral vectors may also be developed to enhance antigen expression and ease of vaccine administration. One report of a recombinant adeno-associated virus vaccine,

1. Citron, M. (2002) Nat. Neurosci. 5, Suppl., 1055-1057.

2. Davis, K. L. \& Samuels, S. C. (1998) in Pharmacological Management of Neurological and Psychiatric Disorders, eds. Enna, S. J. \& Coyle, J. T. (McGrawHill, New York), pp. 267-316.

3. Selkoe, D. (2001) Physiol. Rev. 81, 741-766.

4. McLaurin, J., Yang, D. S., Yip, C. M. \& Fraser, P. E. (2000) J. Struct. Biol. 130, 259-270.

5. Pike, C. J., Walencewicz, A. J., Glabe, C. G. \& Cotman, C. W. (1991) Brain Res. 573, 311-314.

6. Lorenzo, A. \& Yankner, B. (1994) Proc. Natl. Acad. Sci. USA 91, 12243-12247.

7. Iversen, L. L., Mortishire-Sith, R. J., Pollack, S. J. \& Shearman, M. S. (1995) Biochem. J. 311, 1-16.

8. Dodel, R. C., Hampel, H., Depboylu, C., Lin, S., Gao, F., Schock, S., Jackel, S., Wei, X., Buerger, K., Hoft, C., et al. (2002) Ann. Neurol. 52, 253-256.

9. Näslund, J., Haroutunian, V., Mohs, R., Davis, K. L., Davies, P., Greengard, P. \& Buxbaum, J. D. (2000) J. Am. Med. Assoc. 283, 1571-1577.

10. Terry, R. D., Peck, A., DeTeresa, R., Schechter, R. \& Horoupian, D. S. (1981) Ann. Neurol. 10, 184-192.

11. Braak, H. \& Braak, E. (1991) Acta Neuropathol. 82, 239-259. consisting of $\mathrm{A} \beta 1-42$ fused to cholera toxin $\mathrm{B}$ subunit, cleared plaques and improved behavior in the PDAPP mouse (29). Cholera toxin B is the nontoxic subunit and has been shown to act as a non-Th1-inducing adjuvant. DNA vaccines also contain immunostimulatory sequences, such as cytosine-phosphateguanosine repeats, that act as adjuvants. Alternatively, DNA vaccines can be constructed to express the antigen of choice along with an immunomodulatory protein. The chimeric DNA minigene encoding $\mathrm{A} \beta$ fused to mouse IL-4 generated a strong humoral response in wild-type mice (72). The antibodies generated were primarily to the $\mathrm{N}$ terminus, of the $\mathrm{IgG} 1$ and $\mathrm{IgG} 2 \mathrm{a}$ subtype and recognize human amyloid plaques, suggesting not only a Th2 response but also therapeutic potential. To date clinical trials using DNA have required relatively high doses of DNA to elicit immune responses. The development of microparticles and nanoparticles for DNA delivery systems may circumvent this limitation (73). Alternatively, oral vaccines consisting of adeno-associated viral vectors have been shown to induce antibody production for 6 months after a single dose (63). This approach may be safer than intramuscular injections because epithelia lining the gut have a rapid turnover and therefore will decrease the half-life of the vector within the body.

\section{Conclusions}

Insights gained from the pathology, biochemistry, and genetics of $\mathrm{AD}$ have allowed identification of a target for therapy, $\mathrm{A} \beta$, and the generation of transgenic mouse models that recapitulate pathological and behavioral aspects of the disease in which to test hypotheses. The first set of evidence that immunization with $\mathrm{A} \beta$ could reduce $\mathrm{AD}$ pathology and restore cognitive deficits in transgenic mice was met with considerable optimism; this optimism was short-lived, however, because clinical trials of a vaccine were canceled because of a small but significant occurrence of meningoencephalitis. Despite numerous adverse events associated with clinical trials of AN1792, preliminary data demonstrate that vaccination can reduce AD pathology and mitigate progressive cognitive decline associated with the disease. Knowledge gained from studies on A $\beta$ immunotherapy will allow optimization of the vaccine to avoid side effects, while generating a highly specific and effective immune response against what is now believed to be the causative agent of synaptic loss and cognitive decline, $\mathrm{A} \beta$. If this proves successful, $A \beta$ vaccination could provide the first definitive treatment for $\mathrm{AD}$.

This work was supported by the Ontario Alzheimer's Society (P.S.G.-H. and J.M.), Canadian Institutes of Health Research (P.S.G.-H. and J.M.), the Natural Sciences and Engineering Research Council of Canada (J.M.), the Scottish Rite Charitable Foundation (J.M.), the Howard Hughes Foundation (P.S.G.-H.), and the Canadian Genetic Diseases Network (P.S.G.-H.).

12. Dickson, D. W., Crystal, H. A., Bevona, C., Honer, W., Vincent, I. \& Davies, P. (1995) Neurobiol. Aging 16, 285-298.

13. McLean, C. A., Cherny, R. A., Fraser, F. W., Fuller, S. J., Smith, M. J., Beyreuther, K., Bush, A. I. \& Masters, C. L. (1999) Ann. Neurol. 46, $860-$ 666.

14. Klein, W. L., Krafft, G. A. \& Finch, C. E. (2001) Trends Neurosci. 24, 219 224.

15. Gong, Y., Chang, L., Viola, K. L., Lacor, P. N., Lambert, M. P., Finch, C. E., Krafft, G. A. \& Klein, W. L. (2003) Proc. Natl. Acad. Sci. USA 100, 10417-10422.

16. Kayed, R., Head, E., Thompson, J. L., McIntire, T. M., Milton, S. C., Cotman, C. W. \& Glabe, C. G. (2003) Science 300, 486-489.

17. Walsh, D. N., Klyubin, I., Fadeeva, J. V., Cullen, W. K., Anwyl, R., Wolfe, M. S. Rowan, M. J. \& Selkoe, D. J. (2002) Nature 416, 535-539.

18. Schenk, D., Barbour, R., Dunn, W., Gordon, G., Grajeda, H., Guido, T., Hu, K., Huang, J., Johnson-Wood, K., Khan, K., et al. (1999) Nature 400, 173-177.

19. Janus, C., Pearson, J., McLaurin, J., Matthews, P. M., Jiang, Y., Schmidt, S. D., Chishti, M. A., Horne, P., Heslin, D., French, J., et al. (2000) Nature 408, 979-982. 
20. McLaurin, J., Cecal, R., Kierstead, M. E., Tian, X., Phinney, A. L., Manea, M., French, J. E., Lambermon, M. H. L., Darabie, A. A., Brown, M. E., et al. (2002) Nat. Med. 8, 1263-1269.

21. Lemere, C. A., Maron, R., Spooner, E. T., Grenfell, T. J., Mori, C., Desai, R., Hancock, W. W., Weiner, H. L. \& Selkoe, D. J. (2000) Ann. N. Y. Acad. Sci. 920, 328-331.

22. Weiner, H. L., Lemere, C. A., Maron, R., Spooner, E. T., Grenfell, T. J., Mori, C., Issazadeh, S., Hancock, W. W. \& Selkoe, D. J. (2000) Ann. Neurol. 48, 567-579.

23. Bard, F., Cannon, C., Barbour, R, Burke, R., Games, D., Grajeda, H., Guido, T., Hu, K., Huang, J., Johnson-Wood, K., et al. (2000) Nat. Med. 6, 916-919.

24. DeMattos, R. B., Bales, K. R., Cummins, D. J., Dodart, J., Paul, S. M. \& Holtzman, D. M. (2001) Proc. Natl. Acad. Sci. USA 98, 8850-8855.

25. Bard, F., Barbour, R., Cannon, C., Carretto, R., Fox, M., Games, D., Guido, T., Hoenow, K., Hu, K., Johnson-Wood, K., et al. (2003) Proc. Natl. Acad. Sci. USA 100, 2023-2028.

26. Bacskai, B. J., Kajdasz, S. T., Christie, R. H., Carter, C., Games, D., Seubert, P, Schenk, D. \& Hyman, B. T. (2001) Nat. Med. 7, 369-372.

27. Dodart, J., Bales, K. R., Gannon, K. S., Greene, S. J., DeMattos, R. B., Mathis, C., DeLong, C. A., Wu, S., Wu, X., Holtzman, D. M., et al. (2002) Nat. Neurosci. 5, 452-457.

28. Bacskai, B. J., Kajdasz, S. T., McLellan, M. E., Games, D., Seubert, P., Schenk, D. \& Hyman, B. T. (2002) J. Neurosci. 22, 7873-7878.

29. Zhang, J., Xu, S., Qin, J., Ma, S., Zhang, H., Kong, Q., Chen, D., Ba, D. \& He, W. (2003) Neurobiol. Dis. 14, 365-379.

30. Morgan, D., Diamon, D. M., Gottschall, P. E., Ugen, K. E., Dickey, C., Hardy, J., Duff, K., Jantzen, P., DiCarlo, G., Wilcock, D., et al. (2000) Nature 408, 982-985.

31. Das, P., Murphy, M. P., Younkin, L. H., Younkin, S. G. \& Golde, T. E. (2001) Neurobiol. Aging 22, 721-727.

32. Das, P., Howard, V., Loosbrock, N., Dickson, D., Murphy, M. P. \& Golde, T. E. (2003) J. Neurosci. 23, 8532-8538.

33. Wilcock, D. M., Gordon, M. N., Ugen, K. E., Gottschall, P. E., DiCarlo, G., Dickey, C., Boyett, K. W., Jantzen, P. T., Connor, K. E., Melachrino, J., et al. (2001) DNA Cell Biol. 20, 731-736.

34. Lemere, C. A., Spooner, E. T., LaFrancois, J., Malester, B., Mori, C., Leverone, J. F., Matsuoka, Y., Taylor, J. W., DeMattos, R. B., Holtzman, D. M., et al. (2003) Neurobiol. Dis. 14, 10-18.

35. Pfeifer, M., Boncristiano, S., Bondolfi, L., Stalder, A., Deller, T., Staufenbiel, M., Mathews, P. M. \& Jucker, M. (2002) Science 298, 1379.

36. Furlan, R., Brambilla, E., Sanvito, F., Roccatagliata, L., Olivieri, S., Bergami, A., Pluchino, S., Uccelli, A., Comi, G. \& Martino, G. (2003) Brain 126, 285-291.

37. Brazil, M. I., Chung, H. \& Maxfield, F. R. (2000) J. Biol. Chem. 275, 16941-16947.

38. Wilcox, D. M., Munireddy, S. K., Rosenthal, A., Ugen, K. E., Gordon, M. N. \& Morgan, D. (2004) Neurobiol. Dis. 15, 11-20.

39. Ghersi-Egea, J.-F., Gorevic, P. D., Ghiso, J., Frangione, B., Patlak, C. S. \& Fensternacher, J. D. (1996) J. Neurochem. 67, 880-883.

40. Poduslo, J. F., Curran, G. L., Sanyal, B. \& Selkoe, D. J. (1999) Neurobiol. Dis 6, 190-199.

41. Shibata, M., Yamada, S., Kumar, S. R., Calero, M., Bading, J., Frangione, B., Holtzman, D. M., Miller, C. A., Strickland, D. K., Ghiso, J., et al. (2000) J. Clin. Invest. 106, 1489-1499.

42. Dodel, R. C., Hampel, H. \& Du, Y. (2003) Lancet Neurol. 2, 215-220.

43. Solomon, B., Koppel, R., Hanan, E. \& Katzav, T. (1996) Proc. Natl. Acad. Sci. USA 93, 452-455.

44. Solomon, B., Koppel, R., Frankel, D. \& Hanan-Aharon, E. (1997) Proc. Natl. Acad. Sci. USA 94, 4109-4112.
45. Frenkel, D., Katz, O. \& Solomon, B. (2000) Proc. Natl. Acad. Sci. USA 97, 11455-11459.

46. Lombardo, J. A., Stern, E. A., McLellan, M. E., Kajdasz, S. T., Hickey, G. A. Bacskai, B. J. \& Hyman, B. T. (2003) J. Neurosci. 23, 10879-10883.

47. Kotilinek, A., Bacskai, B., Westerman, M., Kawarabayashi, T., Younkin, L. Hyman, B. T., Younkin, S. \& Ashe, K. H. (2002) J. Neurosci. 22, 6331-6335.

48. Lambert, M. P., Viola, K. L., Chromy, B. A., Chang, L., Morgan, T. E., Yu, J., Venton, D. L., Krafft, G. A., Finch, C. E. \& Klein, W. L. (2001) J. Neurochem. 79, 595-605.

49. Schenk, D. (2002) Nat. Rev. Neurosci. 3, 824-828.

50. Senior, K. (2002) Lancet Neurol. 1, 3 (lett.).

51. Orgogozo, J. M., Gilman, S., Dartigues, J. F., Laurent, B., Puel, M., Kirby, L. C., Jouanny, P., Dubois, B., Eisner, L., Flitman, S., et al. (2003) Neurology 61, 46-54.

52. Hock, C., Konietzko, U., Papassotiropoulos, A., Wollmer, A., Streffer, J., von Rotz, R. C., Davey, G., Moritz, E. \& Nitsch, R. M. (2002) Nat. Med. 8, $1270-1275$.

53. Nicoll, J. A. R., Wilkinson, D., Holmes, C., Steart, P., Markham, H. \& Weller, R. O. (2003) Nat. Med. 9, 448-452.

54. Hock, C., Konietzko, U., Streffer, J. R., Tracy, J., Signorell, A., MüllerTilmanns, B., Lemke, U., Henke, K., Moritz, E., Garcia, E., et al. (2003) Neuron 38, 547-554.

55. Ferrer, I., Rovira, M. B., Guerra, M. L. S., Rey, M. J. \& Costa-Jussa, F. (2004) Brain Pathol. 14, 11-20.

56. Weiner, H. L. \& Selkoe, D. J. (2002) Nature 420, 879-884.

57. Grubeck-Loebenstein, B., Blasko, I., Marx, F. \& Trieb, K. (2000) Trends Neurosci. 23, 114 (lett.).

58. Monsonego, A., Zota, V., Karni, A., Krieger, J. I., Bar-Or, A., Bitan, G., Budson, A. E., Sperling, R., Selkoe, D. J. \& Weiner, H. L. (2003) J. Clin. Invest. 112, 415-422.

59. Trieb, K., Ransmayr, G., Sgonc, R., Lassmann, H. \& Grubeck-Loebenstein, B. (1996) J. Clin. Invest. 112, 415-422.

60. Monsonego, A., Maron, R., Zota, V., Selkoe, D. J. \& Weiner, H. L. (2001) Proc. Natl. Acad. Sci. USA 98, 10273-10278.

61. Sigurdsson, E. M., Scholtzova, H., Mehta, P. D., Frangione, B. \& Wisniewski, T. (2001) Am. J. Pathol. 159, 439-447.

62. Leverone, J. F., Spooner, E. T., Lehman, H. K., Clements, J. D. \& Lemere, C. A. (2003) Vaccine 21, 2197-2206.

63. Spinney, L. (2004) Lancet Neurol. 3, 5 (lett.)

64. Neuroinflammation Working Group (2000) Neurobiol. Aging 21, 383-421.

65. Monsonego, A., Imitola, J., Zota, V., Oida, T \& Weiner, H. L. (2003) J. Immunol. 171, 2216-2224.

66. Wyss-Coray, T., Lin, C., Yan, F., Yu, G., Rohde, M., McConlogue, L, Masliah, E. \& Mucke, L. (2001) Nat. Med. 7, 612-618.

67. Cribbs, D. H., Ghochikyan, A., Vasilevko, V., Tran, M., Petrushina, I., Sadzikava, N., Babikyan, D., Kesslak, P., Kieber-Emmons, T., Cotman, C. W., et al. (2003) Int. Immunol. 15, 505-514.

68. Puaux, A. L. \& Michel, M. L. (2003) Comp. Immunol. Microbiol. Infect. Dis. 26, 357-372.

69. Finn, O. J. (2003) Nat. Rev. Immunol. 3, 630-640.

70. Rangan, S. K., Ruitian, L., Brune, D., Planque, S., Paul, S. \& Sierks, M. R. (2003) Biochemistry 42, 14328-14334.

71. Frenkel, D., Solomon, B. \& Benhar, I. (2000) J. Neuroimmunol. 106, 23-31.

72. Ghochikyan, A., Vasilevko, V., Petrushina, I., Movsesyan, N., Babikyan, D. Tian, W., Sadzikava, N., Ross, T. M., Head, E., Cribbs, D. H., et al. (2003) Eur. J. Immunol. 33, 3232-3241.

73. Cui, Z. \& Mumper R. J. (2003) Rev. Ther. Drug Carrier Syst. 20, 103-137. 